\title{
Pengaruh Peran Ganda, Stres Kerja dan Motivasi Kerja Terhadap Kinerja Karyawan Perempuan
}

\author{
Rina Indra Iswari ${ }^{1, *}$, Ari Pradhanawati ${ }^{2}$ \\ ${ }^{1,2}$ Departemen Administrasi Bisnis, Fakultas Ilmu Sosial dan Ilmu Politik, Universitas Diponegoro \\ *Email: rinaindraswari@gmail.com
}

\begin{abstract}
The work force in indonesia along the development of the changes. One of the amendments that is an influx of women in the work force. PT Phapros Tbk is one of the companies in Semarang have female employees who in 2013 until 2016 an up and down in attendance or absentee fluctuant. Both are permitted employee performance can be seen from the dual role, job stress and motivation work. The purpose of this research is to find influence the dual role, job stress and motivation work on performance female employees in PT Phapros Tbk Semarang City. Type research is explanatory research, to technique data collection through the questionnaire and interview. The sample techniques used technique purposive sampling. Sample 100 respondents were is an employee women PT. Phapros Tbk Semarang. This data analyzed using regression analysis. This research result indicates that there was a correlation in the category of strong between variables the dual role, job stress, and motivation work of the performance of employees. Variable free third was proven have a positive influence and significantly to employee performance. The researchers suggest PT Phapros tbk. to be able to create a pleasant working environment, manage stress well, pay attention to the quality and quantity of results of work of employees.
\end{abstract}

\begin{abstract}
Abstraksi Angkatan kerja di Indonesia seiring dengan perkembangan perubahan. Salah satu amandemen tersebut adalah masuknya perempuan dalam angkatan kerja. PT Phapros Tbk adalah salah satu perusahaan di Semarang yang memiliki karyawan wanita yang pada tahun 2013 hingga 2016 tingkat kehadiran atau absen mengalami fluktuasi. Kinerja karyawan dapat dilihat dari peran ganda, stres kerja dan motivasi kerja. Tujuan penelitian ini adalah untuk mengetahui pengaruh peran ganda, stres kerja dan motivasi kerja terhadap kinerja karyawan wanita di PT. Phapros Tbk Kota Semarang. Tipe penelitian adalah penelitian eksplanatori, dengan teknik pengumpulan data melalui angket dan wawancara. Teknik sampel menggunakan teknik purposive sampling. Sampel 100 responden adalah karyawan wanita PT. Phapros Tbk Semarang. Penelitian ini menggunakan teknik analisis regresi. Hasil penelitian ini menunjukkan bahwa terdapat korelasi kuat antara variabel peran ganda, stres kerja, dan motivasi kerja terhadap kinerja karyawan. Variabel bebas ketiga terbukti memiliki pengaruh positif dan signifikan terhadap kinerja karyawan. Peneliti menyarankan PT Phapros tbk. untuk dapat menciptakan lingkungan kerja yang menyenangkan, mengelola stres dengan baik, memperhatikan kualitas dan kuantitas hasil kerja karyawan.
\end{abstract}

Keywords: The Dual Role; Job Stress; Motivation Work; Employee Performance; Women

\section{Pendahuluan}

Angkatan kerja di Indonesia seiring berkembangnya zaman mengalami perubahan. Salah satu dari perubahan tersebut yaitu tidak hanya laki-laki yang bekerja namun perempuan juga ikut berpatisipasi dalam angkatan kerja dan hal ini menjadi fenomena yang menarik. Masuknya perempuan dalam angkatan kerja memunculkan konsekuensi dalam masyarakat bahkan dalam kehidupan pribadi yang bersangkutan. Perempuan yang bekerja cenderung memiliki waktu yang terbatas baik dalam pekerjaan dan keluarga.
Menurut pandangan Cahyaningdyah (2009), adanya gerakan perempuan memasuki dunia kerja menyebabkan perubahan baik dalam masyarakat maupun dalam keluarga dan dalam kehidupan individu yang bersangkutan. Secara ekonomis, adanya pasangan suami istri yang bekerja (two-worker family) menyebabkan peningkatan kesejahteraan keluarga dan masyarakat. Dengan adanya ekstra pendapatan yang mereka terima, keluarga dapat menghadapi inflasi dan kasuskasus lain yang menuntut peningkatan daya beli secara substansial. Pendapatan ganda diharapkan dapat mencukupi segala 
kebutuhan keluarga, termasuk biaya atau keluarga).

pendidikan anak.

Terdapat banyak faktor pendorong yang menyebabkan banyak perempuan yang masuk dalam dunia kerja. Penelitian Uswatun dan Arum (2014) menunjukkan bahwa, kesulitan ekonomi merupakan salah satu faktor pendorong yang membuat ibu rumah tangga dari tingkat ekonomi lemah untuk bekerja. Bekerja dapat membantu mereka meningkatkan pemenuhan kebutuhan keluarga, bahkan ada kondisi dimana perempuan bekerja karena ia satu-satunya sumber penghasilan rumah tangga.

Banyak perempuan yang memiliki peran ganda dan telah berusia 30 tahunan, mereka bekerja sangat keras namun hanya menghasilkan output yang sedikit. Beberapa mengundurkan diri karena merasa sudah tidak kuat untuk melakukan pekerjaan tersebut. Beberapa yang lain mengundurkan diri dari perusahaan karena ingin berkonsentrasi mengurus anak, namun tidak jarang mereka kembali lagi mendaftar ke perusahaan setelah beberapa bulan atau tahun karena terkait pemenuhan kebutuhan ekonomi keluarga (Uswatun \& Arum, 2014).

Para pekerja perempuan sering dihadapkan dengan peran ganda. Perempuan yang mempunyai peran ganda cenderung sulit untuk mengatur waktu dan memiliki waktu yang terbatas terhadap pekerjaan dan keluarga. Menurut Greenhaus dan Beutell (Ratna, dkk, 2014), konflik peran ganda (work family conflict) didefinisikan sebagai suatu bentuk konflik peran dalam diri seseorang yang muncul karena adanya tekanan peran dari pekerjaan yang bertentangan dengan tekanan peran dari keluarga. Selain itu Yang, Chen, Choi, \& Zou (dalam Wirakristama dan Suharnomo, 2011) mengidentifikasikan tiga jenis work-family conflict, yaitu: Time-based conflict. Waktu yang dibutuhkan untuk menjalankan salah satu tuntutan (keluarga atau pekerjaan), Strain-based conflict. Terjadi pada saat tekanan dari salah satu peran mempengaruhi kinerja peran yang lainnya, Behavior-basedconflict. Berhubungan dengan ketidaksesuaian antara pola perilaku dengan yangdiinginkan oleh kedua bagian (pekerjaan
Kesulitan dan tekanan-tekanan yang terjadi dikarenakan oleh peran ganda dapat menyebabkan seseorang menciptakan suatu faktor stressor. Menurut Robbins (dalam Ratna, dkk, 2014) membagi tiga kategori potensi penyebab stres (stressor) yaitu lingkungan, organisasi, dan individu. Selanjutnya ia juga memaparkan bahwa survei yang dilakukan secara konsisten yang telah dilakukan menunjukkan bahwa orang menganggap hubungan pribadi dan keluarga sebagai suatu yang sangat berharga. Kesulitan pernikahan, retaknya hubungan, kesulitan disiplin anak merupakan contoh masalah hubungan yang menciptakan stres bagi karyawan dan dapat terbawa ke tempat kerja. Masalah ekonomi yang dialami oleh individu merupakan perangkat kesulitan pribadi lain yang dapat menciptakan stres bagi karyawan.

Dalam Penelitian yang dilakukan Talitha S, menurut Gibson, dkk (2008), salah satu faktor yang mempengaruhi kinerja yaitu stres kerja. Stres kerja merupakan suatu persepsi penyesuaian, diperantarai oleh perbedaanperbedaan individu dan proses psikologis yang merupakan suatu konsekuensi dari setiap tindakan dari luar atau lingkungan, situasi, atau peristiwa yang menetapkan permintaan psikologis atau fisik berlebihan kepada seseorang. Stres kerja dapat mempengaruhi kinerja seorang individu.

Pada teori di atas disimpulkan bahwa peran ganda pada perempuan menciptakan faktor stresor yang mana stresor tersebut salah satu faktor mempengaruhi kinerja. Sedangkan teori yang dikemukakan (Gibson,dkk., 2003) kinerja dibagi menjadi 3 variabel yaitu: Variabel individu yang terdiri dari kemampuan, ketrampilan, latar belakang pribadi dan demografi, faktor utama yang mempengaruhi adalah perilaku kerja dan kinerja. Variabel psikologis yang terdiri dari variabel persepsi, sikap, kepribadian, belajar dan motivasi, faktor utama yang mempengaruhi adalah keluarga, tingkat sosial dan pengelaman kerja. Variabel organisasi yang terdiri dari sumber daya, kepemimpinan, imbalan, struktur dan desain pekerjaan. 
Teori Gibson menjelaskan bahwa faktor psikologis seperti keluarga, motivasi bahkan stres kerja menjadi faktor utama yang mempengaruhi hasil kinerja karyawan, sehingga dapat disimpulkan bahwa hasil kerja individu tidak akan maksimal apabila kurangnya motivasi baik didalam perusahaan dan didalam keluarga (peran ganda), kurangnya motivasi tersebut meningkatkan stres kerja dan mempengaruhi kinerja karyawan itu sendiri.

Permasalahan dari penelitian ini dapat dirumuskan sebagai berikut: diduga ada peningkatan dan penurunan kinerja karyawan yang dipengaruhi oleh peran ganda, stres kerja dan motivasi kerja karyawan.

Tujuan yang ingin dicapai dalam penelitian ini adalah untuk: (a) mengetahui pengaruh peran ganda terhadap kinerja karyawan perempuan ; (b) mengetahui pengaruh stes kerja terhadap kinerja karyawan perempuan; (c) mengetahui pengaruh motivasi kerja terhadap kinerja karyawan perempuan ; (d) mengetahui pengaruh peran ganda, stres kerja dan motivasi kerja terhadap kinerja karyawan perempuan.

\section{Kajian Teori}

\section{Konflik Peran Ganda (Work-Family Conflict)}

Konflik kerja-keluarga (work family conflict) adalah konflik yang terjadi pada individu akibat menanggung peran ganda, baik dalam pekerjaan (work) maupun keluarga (family), dimana karena waktu dan perhatian terlalu tercurah pada satu peran saja di antaranya (biasanya pada peran dalam dunia kerja), sehingga tuntutan peran lain (dalam keluarga) tidak bisa dipenuhi secara optimal. Konflik pada dasarnya dialami oleh tiap individu apabila dihadapkan oleh dua atau lebih pilihan yang saling bertentangan sedangkan ia harus memilih atau membuat suatu keputusan (Susanto, 2010).

Konflik peran ganda (work family conflict) adalah salah satu bentuk konflik antar peran yang diakibatkan pekerjaan dan keluarga saling tidak cocok satu sama lain, kewajiban pekerjaan yang mengganggu kehidupan rumah tangga, permintaan, waktu dan ketegangan dalam keluarga yang disebabkan harapan dari dua peran yang berbeda (www.psychologymania.com, 2012).

Konflik pekerjaan-keluarga adalah bentuk konflik dimana tuntutan peran dari pekerjaan dan keluarga secara mutual tidak dapat disejajarkan dalam beberapa hal (Ching, dalam Renny Rantika dan Sunjoyo, 2011).

Wanita bekerja dan telah berkeluarga mempunyai dua peranan yang sama penting dimana dalam bekerja wanita dituntut untuk profesional dalam mencapai tujuan perusahaan, sedangkan ketika berada dalam keluarga wanita kembali sebagai kodratnya untuk melayani dan mengurus rumah tangga. Dalam menjalani kedua peran tersebut sekaligus tidak mudah, sehingga dalam pelaksanaannya akan terjadi benturan tanggungjawab antara pekerjaan dengan kehidupan keluarga. Kesulitan dalam memenuhi tuntutan pekerjaan dan keluarga yang sering kali bertentangan dapat menyebabkan terjadinya konflik pekerjaankeluarga (Bedeian, et. al dalam Putri, 2013).

\section{Tipe-tipe Peran Ganda (Work-Family Conflict)}

Menurut pandangan Yang, Chen, Choi, \& Zou (2000) dalam Wirakristama dan Suharnomo (2011) mengidentifikasikan tiga jenis work-family conflict, yaitu: (1) Timebased conflict. Waktu yang dibutuhkan untuk menjalankan salah satu tuntutan (keluarga atau pekerjaan) dapat mengurangi waktu untuk menjalankan tuntutan yang lainnya (pekerjaan atau keluarga); (2) Strain-based conflict. Terjadi pada saat tekanan dari salah satu peranmempengaruhi kinerja peran yang lainnya; (3) Behavior-based conflict. Berhubungan dengan ketidaksesuaian antara polaperilaku dengan yang diinginkan oleh kedua bagian (pekerjaan atau keluarga).

\section{Penyebab Adanya Peran Ganda (Work- Family Conflict)}

Menurut Greenhaus dan Beutell dalam Wirakristama dan Suharnomo (2011) menyatakan bahwa seseorang yang 
mengalami konflik peran ganda akan merasakan ketegangan dalam bekerja. Konflik peran ini bersifat psikologis, gejala yang terlihat pada individu yang mengalami konflik peran ini adalah frustrasi, rasa bersalah, kegelisahan, keletihan. Faktor-faktor penyebab konflik peran ganda, diantaranya: (1) Permintaan waktu akan peran yang tercampur dengan pengambilan bagian dalam peran yang lain; (2) Stres yang dimulai dalam satu peran yang terjatuh ke dalam peran lain dikurangi dari kualitas hidup dalam peran itu; (3) Kecemasan dan kelelahan yang disebabkan ketegangan dari satu peran dapat mempersulit untuk peran yang lainnya; (4) Perilaku yang efektif dan tepat dalam satu peran tetapi tidak efektif dan tidak tepat saat dipindahkan ke peran yang lainnya.

Menurut Frone \& Copper (1992) hal ini biasanya terjadi pada saat seseorang berusaha memenuhi tuntutan peran dalam pekerjaan dan usaha tersebut dipengaruhi oleh kemampuan orang yang bersangkutan untuk memenuhi tuntutan keluarganya, atau sebaliknya, dimana pemenuhan tuntutan peran dalam keluarga dipengaruhi oleh kemampuan orang tersebut dalam memenuhi tuntutan pekerjaannya.

Menurut Nini, et al (2000) tuntutan pekerjaan berhubungan dengan tekanan yang berasal dari beban kerja yang berlebihan dan waktu seperti pekerjaan yang harus diselesaikan terburu-buru dan deadline. Sedangkan tuntutan keluarga berhubungan dengan waktu yang dibutuhkan untuk menangani tugas-tugas rumah tangga. Tuntutan keluarga ini ditentukan oleh besarnya keluarga, komposisi keluarga dan jumlah anggota keluarga yang memiliki ketergantungan terhadap anggota yang lain.

Tuntutan keluarga ini ditentukan oleh besarnya keluarga, komposisi keluarga dan jumlah anggota keluarga yang memiliki ketergantungan terhadap anggota lain (Yang, et al. dalam Wirakristama dan Suharnomo, 2011). Faktor pemicu munculnya konflik peran ganda (work-family conflict) dapat bersumber dari domain tempat kerja dan keluarga. Tekanan-tekanan tersebut berhubungan positif dengan konflik pekerjaan-keluarga.

\section{Stres Kerja}

Menurut Sunyoto (2013) stres mempunyai arti yang berbeda-beda bagi masing-masing individu. Kemampuan setiap orang beraneka ragam dalam mengatasi jumlah, intensitas, jenis dan lamanya stres. Orang lebih mudah membicarakan ketegangan daripada stres. Stres merupakan sesuatu yang menyangkut interaksi antara individu dan lingkungan, yaitu interaksi antara stimulasi dan respons. Jadi stres adalah konsekuensi setiap tindakan dan situasi lingkungan yang menimbulkan tuntutan psikologis dan fisik yang berlebihan pada seseorang.

Dari sudut organisasi, manajemen mungkin tidak khawatir jika karyawannya mengalami stres ringan. Alasannya karena pada tingkat stres tertentu akan memberikan akibat positif, karena hal ini akan mendesak mereka untuk melakukan tugas lebih baik, tetapi pada tingkat stres yang tinggi atau ringan yang berkepanjangan akan membuat menurunnya kinerja karyawan (Sunyoto, 2013).

Menurut Cooper dan Hanger (dalam Waluyo, 2009) stres didefinisikan sebagai tanggapan atau proses internal atau eksternal yang mencapai tingkat ketegangan fisik dan psikologis sampai pada batas atau melebihi batas kemampuan subyek.

Menurut Quick dan Quick (dalam Waluyo, 2009) jenis/tipe stres dikategorikan menjadi dua, yaitu: (1) Eustres yaitu hasil dari respon terhadap stres yang bersifat sehat, positif, dan konstruktif (bersifat membangun). Hal tersebut termasuk kesejahteraan individu dan juga organisasi yang diasosiasikan dengan pertumbuhan, fleksibilitas, kemampuan adaptasi, dan tingkat performance tinggi; (2) Distres yaitu hasil dari respon terhadap stres yang bersifat tidak sehat, negative, dan destruktif (bersifat merusak). Hal tersebut termasuk konsekuensi individu dan juga organisasi seperti penyakit kardivaskular dan tingkat ketidakhadiran yang tinggi, yang diasosiasikan dengan keadaan sakit, penurunan, dan kematian. 
Menurut Handoko (dalam Wirakristama dan Suharnomo, 2011), faktor yang mempengaruhi stres dapat digolongkan menjadi dua penyebab, yaitu: on the job dan off the job. Cooper dan Davidson (dalam Waluyo, 2009) membagi penyebab stres dalam pekerjaan menjadi dua, yaitu: Group stresors dan Individual stressor. Sedangkan menurut Sondang (2013) stres dapat timbul sebagai akibat tekanan atau ketegangan yang bersumber dari ketidakselarasan antara seseorang dengan lingkungannya. Dengan perkataan lain, apabila sarana dan tuntutan tugas tidak selaras dengan kebutuhan dan kemampuan seseorang, ia akan mengalami stres. Biasanya stres semakin kuat apabila seseorang menghadapi masalah yang datangnya bertubi-tubi. Sumber-sumber stres menurut Sondang (2013) pada dasarnya berbagai sumber stres dapat digolongkan pada yang berasal dari pekerjaan dan dari luar pekerjaan seseorang. Berbagai hal yang dapat menjadi sumber stres yang berasal dari pekerjaan pun dapat beraneka ragam seperti beban tugas yang terlalu berat, desakan waktu, sosialisasi yang kurang baik, iklim kerja yang menimbulkan rasa tidak aman, kurangnya informasi dari umpan balik tentang prestasi kerja seseorang, ketidakseimbangan antara wewenang dan tanggung jawab, ketidakjelasan peranan karyawan dalam keseluruhan kegiatan organisasi, frustasi yang menimbulkan oleh intervensi pihak lain yang terlalu sering sehingga seseorang merasa terganggu konsentrasinya, konflik antara karyawan dengan pihak lain di dalam dan di luar kelompok kerjanya, perbedaan sistem nilai yang dianut oleh karyawan dan yang dianut oleh organisasi dan perubahan yang terjadi yang pada umumnya memang menimbulkan rasa ketidakpastian.

Stres yang terlalu besar akan menyebabkan prestasi kerja mulai menurun karena stres mengganggu pelaksanaan pekerjaan. Karyawan kehilangan kemampuan untuk mengendalikannya, menjadi tidak mampu untuk mengambil keputusankeputusan dan perilakunya menjadi tidak teratur. Akibat paling besar adalah prestasi kerja menjadi nol, karena karyawan menjadi sakit atau tidak kuat bekerja lagi, putus asa, keluar atau "melarikan diri" dari pekerjaan, dan mungkin diberhentikan (Handoko, 2008).
Greenberg \& Baron, (dalam Waluyo, 2009) mengatakan bagi perusahaan, dampak yang timbul dan bersifat tidak langsung adalah meningkatnya tingkat absensi, menurunnya tingkat produktivitas, dan secara psikologis dapat menurunkan komitmen organisasi, memicu perasaan teraliensasi, hingga turnover.

Sementara itu, Hasibuan (2011) mengatakan stres pada karyawan dapat mengakibatkan prestasi kerja akan menurun karena karyawan mengalami ketegangan pikiran dan berperilaku yang aneh, pemarah, dan suka menyendiri.

\section{Motivasi Kerja}

Motivasi, berasal dari kata motif (motive), yang berarti dorongan. Dengan demikian motivasi berarti suatu kondisi yang mendorong atau menjadi sebab seseorang melakukan suatu perbuatan/kegiatan, yang berlangsung secara sadar. Banyak pengertian motivasi seperti yang dikemukakan oleh Wexley \& Yukl (1977), memberikan batasan sebagai "the process by which behavior is energized and directed". Mathis \& Jackson (2006), mengatakan, motivasi merupakan hasrat didalam seseorang menyebabkan orang tersebut melakukan suatu tindakan. Seseorang melakukan tindakan untuk sesuatu hal dalam mencapai tujuan. Oleh sebab itu, motivasi merupakan penggerak yang mengarahkan pada tujuan dan itu jarang muncul dengan siasia. Robbins menjelaskan, motivation as the process that account for an individuals intensity, direction, and persistence of effort toward attaining a goal (Bangun, 2012).

McCornick (dalam Mangkunegara, 2011) menjelaskan motivasi kerja sebagai kondisi yang berpengaruh membangkitkan, mengarahkan dalam memelihara perilaku yang berhubungan dengan lingkungan kerja. Sementara itu, Greenberg dan Baron (dalam Wibowo, 2012) berpendapat bahwa motivasi merupakan serangkaian proses yang membangkitkan, mengarahkan, dan menjaga perilaku manusia menuju pada pencapaian tujuan. Membangkitkan berkaitan dengan dorongan atau energi di belakang tindakan. Motivasi juga berkepentingan dengan pilihan 
yang dilakukan orang dan arah perilaku mereka. Sedang perilaku menjaga atau memelihara berapa lama orang akan terus berusaha untuk mencapai tujuan.

Sunyoto (2012) mengidentifikasikan jenis-jenis teori motivasi, salah satunya adalah teori kepuasan (content theory). Teori ini mendasarkan pada faktor-faktor kebutuhan dan kepuasan individu sehingga mereka mau melakukan aktivitasnya, jadi mengacu pada diri seseorang. Teori ini mencoba mencari tahu tentang kebutuhan apa yang dapat memuaskan dan yang dapat mendorong semangat kerja seseorang. Misal: teori hierarki kebutuhan dari Maslow (dalam Sunyoto, 2012) dan teori ERG (Existence, Relatedness, and Growth) dari Aldefer (dalam Sunyoto, 2012) serta teori dua faktor dari Herzberg (dalam Sunyoto, 2012). Dari hasil penelitian Herzberg menyimpulkan dua hal atau dua faktor yang mempengaruhi sikap seseorang terhadap pekerjaannya yang disebut dengan faktor pemuas kerja (job satisfier) dan faktor penyebab ketidakpuasan kerja (job dissatifier) yang berkaitan dengan suasana pekerjaan. Faktor-faktor pemuas disebut juga "Motivator" dan faktor penyebab ketidakpuasan kerja disebut faktor higienis (hygiene factors). Dan teori motivasi prestasi dari Mc. Clelland (dalam Sunyoto, 2012). Teori ini menyatakan bahwa seseorang bekerja memiliki energi potensial yang dapat dimanfaatkan tergantung pada dorongan motivasi, situasi, dan peluang yang ada. Selanjutnya David Mc.Clelland meneliti tiga jenis kebutuhan, yaitu: kebutuhan akan prestasi, kebutuhan akan afiliasi, dan kebutuhan akan kekuasaan (Sunyoto, 2012).

Faktor-Faktor yang Mempengaruhi Motivasi Kerja

Faktor-faktor motivasi kerja Menurut Robert Kreitner dan Angelo Kinicki (dalam Wibowo, 2012:391-399) menyatakan bahwa motivasi dapat diperoleh melalui: Needs (kebutuhan), Job design (desain pekerjaan), Satisfaction (kepuasan), Equity (keadilan), Expectation (harapan), dan Goal Setting (penetapan tujuan).

\section{Manfaat Motivasi Kerja}

Menurut Ishak \& Tanjung (2004) manfaat motivasi yang utama adalah menciptakan gairah kerja sehingga produktivitas kerja meningkat. Sementara itu, manfaat bekerja dengan orang yang termotivasi adalah pekerjaan dapat diselesaikan dengan tepat, artinya pekerjaan diselesaikan sesuai standar yang besar dan dalam skala waktu yang sudah ditentukan.

Ciri-ciri orang yang termotivasi menurut Ishak \& Tanjung (2004) orang yang termotivasi memiliki ciri-ciri: bekerja sesuai dengan standar yang benar dan dalam waktu yang sudah ditentukan, merasa senang melakukan pekerjaannya, merasa pekerjaannya betul-betul berharga, akan bekerja keras untuk menghasilkan sesuai target yang ditetapkan, sedikit pengawasan karena kinerjanya akan dipantau oleh individu yang bersangkutan sendiri, dan semangat juangnya akan tinggi. Sedangkan seseorang yang tidak termotivasi karena timbul perasaan tidak puas dalam dirinya akan menunjukkan tanda-tanda yaitu: tidak mau bekerja sama pada waktu usaha ekstra diperlukan, segan menjadi sukarela untuk melakukan pekerjaan ekstra, datang terlambat tetapi pulang lebih awal/tidak masuk kerja satu hari tanpa keterangan, memperpanjang waktu bebas dari pekerjaan, tidak menempati batas waktu karena tugas tidak dapat diselesaikan secara tepat waktu, tidak memiliki sifat-sifat standar yang dikehendaki, terus menerus mengeluh tentang hal-hal sepele, menyalahkan orang lain pada keadaan tidak berjalan lancar, tidak mau mematuhi instruksi.

\section{Kinerja Karyawan}

Istilah kinerja berasal dari kata $J o b$ Performance atau Actual Performance (prestasi kinerja atau prestasi sesungguhnya yang dicapai oleh seseorang). Pengertian kinerja (prestasi kerja) adalah hasil kerja secara kualitas dan kuantitas yang dicapai oleh seorang pegawai dalam melaksanakan tugasnya sesuai dengan tanggung jawab yang diberikan kepadanya (Mangkunegara, 2008). 
Manajemen kinerja merupakan proses mengkonsolidasikan penetapan tujuan, penilaian dan pengembangan kinerja ke dalam satu sistem tunggal bersama, yang bertujuan memastikan kinerja karyawan mendukung tujuan strategis perusahaan (Dessler, 2008).

Menurut Deming (dalam Dessler, 2008) pada dasarnya kinerja karyawan lebih merupakan fungsi dari pelatihan, komunikasi, alat, dan pengawasan daripada motivasi pribadi. Penekanan manajemen kinerja pada penetapan tujuan, penilaian, dan pengembangan yang terpadu menggambarkan asumsi ini.

Menurut Gibson kinerja dibagi menjadi 3 variabel yaitu: Variabel individu yang terdiri dari kemampuan, ketrampilan, latar belakang pribadi dan demografi, faktor utama yang mempengaruhi adalah perilaku kerja dan kinerja. Variabel psikologis yang terdiri dari karyawan perempuan di PT. Phapros Tbk yang sudah bersuami dan mempunyai anak sebesar 2.753 orang. Teknik pengambilan sampel dilakukan dengan metode purposive sampling. Jumlah sampel yang diambil berdasarkan rumus Slovin adalah 100 orang. Teknik pengumpulan data menggunakan kuesioner. Skala pengukurannya menggunakan Skala Likert. Analisis data menggunakan skor rata-rata, regresi linier sederhana dan regresi linier berganda.

\section{Hasil}

Hasil Uji Regresi Linier Sederhana antara Peran Ganda, Stres Kerja dan Motivasi dengan Kinerja Karyawan ditunjukkan pada Tabel 6.

\section{Pembahasan}

Tabel 6. Hasil Uji Regresi Linier Sederhana antara Peran Ganda, Stres Kerja dan Motivasi dengan Kinerja Karyawan

\begin{tabular}{llllll}
\hline Model & B & $\begin{array}{l}\text { Std. } \\
\text { Error }\end{array}$ & Beta & t & Sig. \\
\hline Peran Ganda: & & & & & \\
$Y=10,910+0,167 X_{1}$ &, 167 &, 042 &, 369 & 3,933 &, 000 \\
$\begin{array}{l}\text { Stres Kerja }\left(\mathrm{X}_{2}\right): \\
\text { Y }\end{array}$ &, 079 &, 029 &, 265 & 2,716 &, 008 \\
$\begin{array}{l}\text { Motivai Kerja }\left(\mathrm{X}_{3}\right): \\
Y\end{array}$ & & & & & \\
$Y=10,092+0,332 \mathrm{X}_{3}$ &, 332 &, 065 &, 458 & 5,096 &, 000 \\
\hline
\end{tabular}

Dependent Variable (Y): Kinerja Karyawan

variabel persepsi, sikap, kepribadian, belajar dan motivasi, faktor utama yang mempengaruhi adalah keluarga, tingkat sosial dan pengalaman kerja. Variabel organisasi yang terdiri dari sumber daya, kepemimpinan, imbalan, struktur, dan desain pekerjaan (Gibson, dkk 2003).

\section{Metode}

Penelitian ini dilaksanakan di PT. Phapros Tbk di Kota Semarang. Variabel yang diteliti adalah peran ganda $\left(\mathrm{X}_{1}\right)$, stres kerja $\left(\mathrm{X}_{2}\right)$, motivasi kerja $\left(\mathrm{X}_{3}\right)$ terhadap kinerja karyawan (Y). Tipe penelitian ini explanatory research. Populasi dalam penelitian ini adalah
Berdasarkan hasil penelitian ini, dapat dibuktikan ada pengaruh peran ganda, stres kerja, dan motivasi kerja terhadap kinerja karyawan. Hipotesis pertama yang menyatakan bahwa ada pengaruh antara peran ganda terhadap kinerja karyawan adalah terbukti. Hal tersebut terlihat dari hasil koefisien korelasi atau tingkat keeratan hubungan antara variabel peran ganda terhadap variabel kinerja karyawan adalah sebesar 0,369. Hasil penelitian ini menunjukkan bahwa kekuatan asosiasi (hubungan) linear antara variabel peran ganda terhadap kinerja karyawan adalah rendah. Kinerja karyawan telah dipengaruhi oleh peran ganda sebesar 13,6\%. Sedangkan 
berdasarkan uji t, dapat diketahui bahwa $\mathrm{t}$ hitung $(3,933)>\mathrm{t}$ tabel $(1,9845)$ yang memiliki kesimpulan bahwa menerima hipotesis pertama yang berbunyi ada pengaruh antara peran ganda terhadap kinerja karyawan. Seperti teori yang dikatakan oleh Greenhouse and Beutell (1985) yang menyatakan bahwa konflik peran ganda adalah sebuah konflik yang timbul akibat tekanan-tekanan yang berasal dari pekerjaan dan keluarga, yang kemudian diidentifikasi menjadi 3 jenis oleh Yang, Chen, Choi \& Zou (2000) yaitu waktu yang dibutuhkan (time-based conflict), tekanan salah satu peran (stain-basedconflict), ketidaksesuaian antar pola perilaku (behaviour-based conflict), selain itu menurut Christine (2010) konflik peran ganda berkorelasi dengan ketidakhadiran, produktivitas dan dapat mempengaruhi kinerja. Berdasarkan teori tersebut maka dapat disimpulkan bahwa karyawan perempuan mengalami peran ganda yang berasal dari pekerjaan dan keluarga sehingga dapat mempengaruhi hasil kinerja.

Berdasarkan penelitian yang dilakukan pada hipotesis kedua yang menyatakan bahwa ada pengaruh stres kerja terhadap kinerja karyawan adalah terbukti. Hal tersebut terlihat dari hasil koefisien korelasi atau tingkat keeratan hubungan antara variabel stres kerja terhadap variabel kinerja karyawan adalah sebesar 0,265. Hasil perhitungan ini menunjukkan bahwa kekuatan asosiasi (hubungan) linear antara variabel peran ganda terhadap kinerja karyawan adalah rendah. Kinerja karyawan dipengaruhi oleh stres kerja sebesar $0,07 \%$. Sedangkan berdasarkan uji $t$, dapat diketahui bahwa $\mathrm{t}$ hitung $(3,696)>\mathrm{t}$ tabel $(1,9845)$ yang memiliki kesimpulan bahwa menerima hipotesis kedua yang berbunyi ada pengaruh antara stres kerja terhadap kinerja karyawan. Seperti teori yang dinyatakan oleh Handoko (2008:200) stres yang terlalu besar akan menyebabkan prestasi kerja mulai menurun karena stres mengganggu pelaksanaan pekerjaan, stres merupakan ketegangan yang mempengaruhi emosi, proses berfikir dan kondisi seseorang. Jadi apabila stres kerja meningkat terutama stres ringan dapat memicu karyawan untuk bekerja lebih baik sehingga dapat meningkatkan kinerja karyawan.
Berdasarkan hipotesis ketiga yang menyatakan bahwa terdapat pengaruh antara motivasi kerja terhadap kinerja karyawan adalah terbukti. Hal tersebut terlihat dari hasil koefisien korelasi atau keeratan hubungan antara variabel motivasi kerja terhadap variabel kinerja karyawan adalah sebesar 0,458 . Hasil perhitungan ini menunjukkan bahwa kekuatan asosiasi (hubungan) linear antara variabel motivasi kerja terhadap kinerja karyawan adalah rendah. Kinerja karyawan telah dipengaruhi oleh motivasi kerja sebesar $20,9 \%$. Sedangkan berdasarkan uji t, dapat diketahui bahwa $\mathrm{t}$ hitung $(5,096)>\mathrm{t}$ tabel $(1,9845)$ yang memiliki kesimpulan bahwa menerima hipotesis ketiga yang berbunyi ada pengaruh antara motivasi kerja terhadap kinerja karyawan. Hal ini sesuai dengan Teori ERG yag dikemukakan oleh Aldefer mengisyaratkan bahwa individu akan termotivasi untuk melakukan sesuatu guna memenuhi salah satu dari ketiga perangkat kebutuhan yaitu eksistensi, keterikatan, dan pertumbuhan (Sunyoto, 2012). Selain itu dalam teori yang dikemukakan oleh Ishak \& Tanjung (2004) manfaat motivasi yang utama adalah menciptakan gairah kerja sehingga produktivitas kerja meningkat. Sementara itu, manfaat bekerja dengan orang yang termotivasi adalah pekerjaan dapat diselesaikan dengan tepat, artinya pekerjaan diselesaikan sesuai standar yang besar dan dalam skala waktu yang sudah ditentukan. Jadi semakin baik motivasi yang diperoleh karyawan wanita maka akan mempengaruhi kinerja karyawan di PT Pharpros Tbk Semarang.

Hipotesis keempat yang menyatakan bahwa terdapat pengaruh antara peran ganda, stres kerja, dan motivasi kerja terhadap kinerja karyawan perempuan adalah terbukti. Hal ini ditunjukkan melalui tingkat keeratan hubungan antara keempat variabel tersebut yaitu sebesar 0,608. Hal ini berarti 33,6\% kinerja karyawan dapat dijelaskan oleh peran ganda, stres kerja dan motivasi kerja. Sedangkan pada uji $\mathrm{F}$ telah menunjukkan $\mathrm{F}$ hitung $(16,168)>\mathrm{F}$ tabel $(2,703)$ dimana dikatakan bahwa ada pengaruh antara peran ganda, stres kerja, dan motivasi kerja secara bersama-sama terhadap kinerja karyawan perempuan di PT Phapros Tbk Kota Semarang. Hal ini sesuai dengan teori yang 
dikemukakan oleh Gibson,dkk (2003) kinerja dibagi menjadi 3 variabel yaitu: Variabel individu yang terdiri dari kemampuan, ketrampilan, latar belakang pribadi dan demografi, faktor utama yang mempengaruhi adalah perilaku kerja dan kinerja. Variabel psikologis yang terdiri dari variabel persepsi, sikap, kepribadian, belajar dan motivasi, faktor utama yang mempengaruhi adalah keluarga, tingkat sosial dan pengelaman kerja. Variabel organisasi yang terdiri dari sumber daya, kepemimpinan, imbalan, struktur dan desain pekerjaan.

Dapat dijelaskan sesuai dengan hasil penelitian dan teori diatas bahwa kinerja dipengaruhi oleh berbagai faktor yang menjadi faktor utama dalam penelitian ini adalah faktor psikologis yaitu keluarga (peran ganda), stres kerja dan motivasi kerja. Jadi peran ganda, stres kerja dan motivasi kerja merupakan faktor yang penting untuk mengetahui tingkat kinerja karyawan perempuan di PT Phapros Tbk Kota Semarang.

\section{Kesimpulan dan Saran}

Berdasarkan hasil penelitian yang dilakukan tentang pengaruh peran ganda, stres kerja, dan motivasi kerja terhadap kinerja karyawan perempuan di PT Phapros Tbk Kota Semarang, maka penulis dapat mengambil kesimpulan sebagai berikut: peran ganda memiliki pengaruh terhadap kinerja karyawan perempuan di PT Phapros Tbk Kota Semarang, hal ini dibuktikan dengan hipotesis pertama yang berbunyi "Ada pengaruh peran ganda terhadap kinerja karyawan perempuan" diterima dengan $t$ hitung lebih besar dari $t$ tabel. Peran ganda yang dialami karyawan perempuan berada pada taraf yang rendah. Hal ini menunjukkan bahwa karyawan perempuan jarang merasakan adanya peran ganda seperti tidak adanya waktu untuk keluarga dan kehidupan bermasyarakat, penggunaan hari libur untuk bekerja, keluarga mempengaruhi pekerjaan, pekerjaan mempengaruhi keluarga, keluhan dari keluarga, keluarga yang tidak mendapatkan dukungan peran sebagai ibu rumah tangga, dan kelelahan setelah pulang bekerja. Stres kerja memiliki pengaruh terhadap kinerja karyawan perempuan di PT
Phapros Tbk Kota Semarang, hal ini dibuktikan dengan hipotesis kedua yang berbunyi "Ada pengaruh stres kerja terhadap kinerja karyawan perempuan" diterima dengan t hitung lebih besar dari t tabel. Stres kerja yang dialami karyawan perempuan berada pada taraf yang rendah. Hal ini menunjukkan bahwa karyawan jarang merasakan beban kerja yang berat, tekanan atau desakan waktu, kualitas supervisi yang buruk, iklim politis yang tidak nyaman, umpan balik kinerja yang kurang memadai, wewenang yang tidak mencukupi, ketidakjelasan peran, frustrasi, perbedaan nilai-nilai perusahaan dengan karyawan, berbagai bentuk perubahan di perusahaan, masalah keuangan, masalah yang berhubungan dengan keluarga, dan berbagai macam perubahan di tempat tinggal. Motivasi kerja memiliki pengaruh terhadap kinerja karyawan perempuan PT Phapros Tbk Kota Semarang, hal ini dibuktikan dengan hipotesis ketiga yang berbunyi "Ada pegaruh motivasi kerja terhadap kinerja karyawan perempuan" diterima dengan $\mathrm{t}$ hitung lebih besar dari $\mathrm{t}$ tabel. Motivasi kerja yang dialami karyawan berada pada taraf sedang. Hal ini menunjukkan bahwa karyawan akan mengalami motivasi apabila mendapatkan imbalan secara financial (kebutuhan materi), hubungan yang baik dengan keluarga dan perusahaan, adanya keinginan karyawan untuk lebih produktif. Variabel independen yaitu peran ganda, stres kerja dan motivasi kerja secara simultan berpengaruh terhadap kinerja karyawan perempuan, dibuktikan dengan hasil $\mathrm{F}$ hitung lebih besar dari $\mathrm{F}$ tabel. Maka dapat diasumsikan bahwa peran ganda rendah, stres kerja rendah, dan motivasi kerja sedang maka akan kinerja karyawan akan semakin meningkat. Sebaliknya, jika peran ganda baik, stres kerja tinggi dan motivasi kerja rendah maka kinerja karyawan akan menurun. Motivasi kerja mempunyai peran besar bagi karyawan untuk meningkatkan kinerja karyawan. Karyawan perempuan yang termotivasi saat bekerja akan membantu meningkatkan kinerja karyawan perempuan.

Berdasarkan hasil penelitian yang telah dilakukan pada karyawan perempuan PT Phapros Tbk Kota Semarang, maka penulis memberikan saran sebagai berikut: variabel produktivitas karyawan berada pada tingkat 
yang paling rendah. Diharapkan karyawan dapat bekerja lebih profesional dan tidak menggabungkan antara masalah keluarga dengan masalah pekerjaan sehingga tidak mempengaruhi hasil kinerjanya. Variabel stres kerja terdapat beberapa indikator yang bernilai rendah yaitu konflik antar kelompok atau individu dan kesehatan/fisik. Dapat disimpulkan bahwa faktor utama yang mempengaruhi stres kerja ini adalah karyawan merasa terganggu apabila terjadi konflik antar individu ataupun konflik antar kelompok, selain itu jika karyawan merasa tidak sehat, maka akan mengganggu pikirannya dan berimbas terhadap kinerjanya. Diharapkan stres kerja dapat dikelola dengan baik sehingga tidak menjadi stres yang tinggi dan berkepanjangan yang dapat menurunkan tingkat kinerja karyawan. Sebaiknya perusahaan tetap mempertahankan dan meningatkan motivasi kerja yang baik agar kinerja karyawan lebih meningkat. Agar pekerjaan yang dihasilkan karyawan dapat menghasilkan kinerja yang optimal, maka perusahaan diharapkan dapat menciptakan lingkungan kerja yang menyenangkan.

Dalam upaya meningkatkan kinerja karyawan perempuan PT Pharos Tbk Kota Semarang, beberapa hal yang perlu diperhatikan perusahaan adalah kualitas hasil pekerjaan individu dan ketepatan waktu dalam menyelesaikan tugas. Selain peran ganda, stres kerja dan motivasi kerja karena faktorfaktor tersebut memiliki pengaruh terhadap tingkat kinerja karyawan perempuan.

\section{Daftar Referensi}

Astianto, Anggit, Heru Suprihadi. (2014). Pengaruh Stres Kerja dan Beban Kerja Terhadap Kinerja Karyawan PDAM Surabaya. Jurnal Ilmu \& Riset Manajemen, Vol. 3 No. 7,1-13.

Ayu, Ida, dkk. (2014). Pengaruh Konflik Peran, Ketidakjelasan Peran dan Kelebihan Peran pada Kinerja Auditor dengan Kecerdasaan Emosional sebagai Variabel Pomederasi (Studi Empiris pada Kantor Akuntan Publik Se-Provinsi Bali).
Bangun, Wilson. (2012). Manajemen Sumber Daya Manusia. Jakarta: Erlangga.

Cahyaningdyah, Dwi. (2009). Analisis Konflik Pekerjaan Keluarga Pada Wanita Pekerja di Industri Perbankan. Dinamika Manajemen, Vol. 1, No. 1, November, hal 10-18.

Christine, Merlyn. (2010). Hubungan Dukungan Keluarga dengan Respon Cemas Anak Usia Sekolah terhadap Pemasangan Intravena di Rumah Sakit Advent Medan. Diambil pada tanggal 04 April 2016 dari http://repository.usu.ac.id/

Daryanti, Wrismi. dkk. (2015). Pengaruh Konflik Peran Ganda, Kompensasi, Dan LingkunganKerja Terhadap Kinerja Pekerja Wanita Melalui Komitmen Organisasi Pada PT. Mangli Djaya Raya. Artikel Ilmiah 2015. Hal 1-7.

Dessler, G. (2008). Human Resource Management. 11th Edition, New Jersey: Pearson Education.

Frone, Russell dan Cooper. (1992). Relationship Between Job and Family Satisfaction. Journal of Management, 565-579.

Ghozali, Imam. (2005). Aplikasi Analisis Multivariate dengan program SPSS. Semarang: Badan Penerbit Universitas Diponegoro.

Gibson. dkk. (2003). Organizations: Behavior Structure Processes. Eleventh Edition. NewYork: Mc Graw Hill.

Handoko, T. Hani. (2002). Manajemen: Edisi Kedua, Cetakan Ketiga belas. Yogyakarta: BPFE.

Handoko, T. Hani. (2008). Manajemen Personalia dan Sumber Daya Manusia. Yogyakarta: PT. BPFE.

Hasibuan, Malayu S.P. (2011). Manajemen Sumber Daya Manusia. Jakarta: PT Bumi Aksara. 
Ishak A., dan Hendri Tanjung. (2004). Manajemen Motivasi. Jakarta: PT Grasindo.

Khasanah, Uswatun dan Arum Darmawati. (2014). Pengaruh Konflik Peran Ganda dan MotivasiKerja Terhadap Kinerja Karyawati PT Cosmoprof Indokarya, Jurnal Manajemen Bisnis Indonesia, Tahun 2014, hal 1-5.

Lestari, Eni. (2014). Pengaruh Lingkungan Keluarga dan Motivasi Belajar Terhadap Prestasi Belajar Matematika Siswa Kelas IV Se Kecamatan Turi Sleman Yogyakarta Tahun Ajaran 2014/2015. Diambil pada tanggal 15 September 2016 dari http://repository.upy.ac.id/320/.

Mahardhika, Rangga, Djamhur Hamid, dan Ika Ruhana. (2013). Pengaruh Motivasi Kerja Terhadap Kinerja Karyawan (Survei Karyawan Pada PT. Axa Financial Indonesia Sales Office Malang). Fakultas Ilmu Administrasi Universitas Brawijaya Malang, hal 1-10.

Mangkunegara, Anwar Prabu. (2008). Manajemen Sumber Daya Manusia Perusahaan. Bandung: PT Remaja Rosdakarya.

Mangkunegara, Anwar Prabu. (2011). Manajemen Sumber Daya Manusia Perusahaan. Bandung: PT Remaja Rosdakarya.

Putri, Rizky Herwinda. (2013). Analisis Pengaruh Stres Kerja dan Konflik Pekerjaan-Keluarga (Work Family Conflict) Terhadap Kinerja Karyawan dengan Kepuasan Kerja Sebagai Variabel Intervening (Studi pada PT Ara Shoes Indonesia). Skripsi. Semarang: Diponegoro.

Rantika dan Renny Sunjoyo. (2011). Pengaruh Konflik Kerja-Keluarga Terhadap Komitmen Organisasional Yang Dimediasi Oleh Kepuasan Kerja Pada Profesi Perawat Di Rumah Sakit Umum Daerah (RSUD) Dr. Moewardi Surakarta. Jurnal Manajemen Teori dan
Terapan, Tahun 4, No. 2, Agustus, hal 28-43.

Reksohadiprodjo, Soekanto, dan Hani Handoko. (1996). Organisasi Perusahaan: Teori, Struktur dan Perilaku. Yogyakarta: BPFE.

Sari, Ratna Kartika, Nasir Azis, Amri. (2014). Pengaruh Konflik Peran Ganda dan Stres Kerja Terhadap Kinerja Pemeriksaan BPK RI Perwakilan Provinsi Aceh. Jurnal Manajemen, Vol 3,No 2, Mei, Hal. 29-34.

Siagian, Sondang P. (2013). Manajemen Sumber Daya Manusia. Jakarta: Bumi Aksara.

Sinungan. (2009). Produktivitas Apa dan Bagaimana. Jakarta: PT Bumi Aksara.

Sugiyono. (2010). Metodologi Penelitian Bisnis. Bandung: CV Alfabeta.

Sunyoto, Danang. (2013). Manajemen Sumber Daya Manusia. Jakarta: Buku Seru.

Susanto. (2010). Analisis Pengaruh Konflik Kerja-Keluarga Terhadap Kepuasan Kerja Pengusaha Wanita di Kota Semarang. Jurnal, 12 (1): 75-85.

Talitha S., Rubina, Bernadetta Junita Santosa. (2008). Hubungan Konflik Peran Ganda (Work-Family Conflict) Dengan Kinerja Karyawan Wanita PT. Matahari Kahuripan Indonesia.

Umar, Husein. (2002). Metode Riset Bisnis. Jakarta: PT Gramedia Pustaka.

Wahyono, Teguh. (2012). Analisis Statistik Mudah dengan SPSS 20. Jakarta: PT Elex Media Komputindo.

Waluyo, Minto. (2009). Psikologi Teknik Industri. Yogyakarta: Graha Ilmu.

Wibowo. (2012). Manajemen Kinerja. Jakarta: PT Raja Grafindo Persada. 
Wirakristama, RC, Suharnomo. (2011). Analisis Pengaruh Konflik Peran Ganda (Work Family Conflict) Terhadap Kinerja Karyawan Wanita Pada Pt Nyonya Meneer Semarang Dengan Stres Kerja Sebagai Variabel Intervening. Diambil pada tanggal 15 Agustus2016 dari http://eprints.undip.ac.id/32813/.

Wirawan, Nata. (2002). Cara Mudah Memahami Statistik 2 (Statistik Inferensia) Untuk Ekonomi dan Bisnis. Edisi Kedua. Denpasar: Keramat Emas.
Yang Nini, et al. (2000). Sources of WorkFamily Conflict: A Sino-U.S Comparison of The Effects of Work and Family Demands. Academy of Management Journal, Vol. 43, No. 1, 113-123.

Yavas, U \& Babakus, E. (2008). Attitudinal And Behavioral Consequences of WorkFamily Conflict And Family-Work Conflict: Does Gender Matter? International Journal of Service Industry Management. Vol. 19. No. 1. 